\title{
Lactational effects of adding a fibrolytic enzyme complex to the concentrate of lactating dairy goats*
}

\author{
E. González ${ }^{1,2}$, G. Caja ${ }^{1}$, E. Albanell ${ }^{1,3}$, C. Flores ${ }^{1}$, R. Casals ${ }^{1}$ \\ and X. Such ${ }^{1}$ \\ ${ }^{1}$ Research Group in Ruminants, Animal and Feed Science Department, \\ Universitat Autònoma de Barcelona (UAB) \\ 08193 Bellaterra, Spain \\ ${ }^{2}$ Experimental Station of Pasture and Forages 'Indio Hatuey' \\ Central España Republicana, 44280 Matanzas, Cuba
}

(Received 14 September 2007; revised version 26 May 2008; accepted 24 June 2008)

\begin{abstract}
Twenty-four multiparous Murciano-Granadina dairy goats in mid-lactation (wk 8 to 30) were used in a single cross-over design to evaluate the effects of supplementation with an exogenous fibrolytic enzyme preparation, characterized by cellulase and xylanase activities, on feed intake, milk yield and composition, and liveweight and body condition changes. Goats received ad libitum a basal total mixed ration composed of $65 \%$ forage and $35 \%$ concentrate. The treatments were: control (without enzyme) and experimental with enzyme (included at the recommended commercial dose of $4.7 \mathrm{ml} / \mathrm{kg}$ concentrate). Feed intake, milk yield, $4 \%$ fat corrected milk yield, and milk composition were not affected by enzyme supplementation, although milk casein content tended to decrease in the enzyme treatment. Body weight change tended to be higher with the enzyme treatment.
\end{abstract}

KEY WORDS: fibrolytic enzyme, lactation, milk, dairy goat

\section{INTRODUCTION}

Enzyme preparations (concentrated fermentation products) containing high levels of cellulase, xylanase and pectinase have been used to improve the nutritive

\footnotetext{
* Supported partially by a Grant from the MEC (Ministerio de Educación y Ciencia) of Spain (Project CICYT AGL2001-2617) and Agribrands Europe-España, S.A. (Barcelona, Spain)

${ }^{2}$ Present address: INRA UR143 Unité de Recherches Zootechniques, Centre INRA-Antilles-Guyane, Domain Duclos, 97170 Petit Bourg, Guadeloupe, French West Indies

${ }^{3}$ Corresponding author: e-mail: elena.albanell@uab.cat
} 
quality of forages and silages and diets of non-ruminant species (Chesson, 1993; Bhat, 2000). Nevertheless, the results of adding enzyme preparations to ruminant diets are variable in practice. Although several studies have shown substantial improvements in feed digestibility and animal performance in dairy cows (Beauchemin et al., 1999; Rode et al., 1999; Yang et al., 1999), others reported either negative effects (Kung et al., 2000) or none at all (Beauchemin et al., 2000). This inconsistency in ruminants could be attributed to differences in diet composition, type of enzyme preparation, complement of enzyme activities, amount of enzyme provided, enzyme stability, method of application, and proportion of the diet to which enzymes are added, as well as animal differences (Yang et al., 1999; Bowman et al., 2002; Beauchemin et al., 2003). Beauchemin et al. (2003) concluded that ruminant responses are greatest when fibre digestion is compromised or when energy is the first limiting factor in the diet.

Although many experiments on enzymes have been conducted in dairy cows (Beauchemin et al., 2003), only a few results have been reported in sheep (Flores et al., 2002, 2008; Pinos-Rodríguez et al., 2002; Titi and Lubbadeh, 2004) or in goats (Titi and Lubbadeh, 2004). The last authors refer to the short time effects of enzymes in suckling goats and, to our knowledge, no enzyme effects have been reported in dairy goats.

The aim of this study was to evaluate the effects of using an exogenous fibrolytic enzyme preparation, characterized by cellulase and xylanase activities, on lactation performance of Murciano-Granadina dairy goats.

\section{MATERIAL AND METHODS}

The experiment was conducted on the Experimental Farm of the S1GCE (Farm and Experimental Campus Service) of the Universitat Autònoma de Barcelona (UAB) in Bellaterra (Spain). Experimental procedures were approved by the Ethical Committee on Human and Animal Experimentation of the UAB.

\section{Animals, management and diets}

Twenty-four multiparous Murciano-Granadina dairy goats at the beginning of mid lactation ( $35 \pm 9$ days in milk) were divided into two groups (12 goats per group) according to number of lactation and to milk yield, body weight (BW, $41.7 \pm 1.4 \mathrm{~kg}$ ) and body condition score (BCS, 2.38 \pm 0.04 ) between wk 8 and 10 of parturition. Goats groups were placed in separated pens which were randomly assigned to the 2 dietary treatments. Experimental design lasted from wk 11 to 26, corresponding to the linear phase of the lactation curve in the breed, and consisted of a single cross- 
over trial divided into two measurement periods of $42 \mathrm{~d}$ with an adaptation period of $14 \mathrm{~d}$ (wk 11 and 12) and an intermediate washing-out period of $14 \mathrm{~d}$ (wk 19 and 20). Performance recording between wk 8 and 10 was used for allocating animals in experimental groups. Treatments were: control (concentrate without enzyme) and enzyme (concentrate with the fibrolytic enzyme preparation; Promote, Agribrands International, St. Louis, Missouri, USA). Goats were group fed ad libitum a total mixed ration (TMR) based on $65 \%$ forage (dehydrated mixture of $50 \%$ lucerne and $50 \%$ maize-whole plant) and 35\% concentrate pellets (on fresh matter basis) to which the fibrolytic enzyme preparation was or was not added. Diet ingredients and nutritional composition are summarized in Tables 1 and 2.

Table 1. Ingredient composition of the experimental diets, $\%$ as fed

\begin{tabular}{lcc}
\hline Item & Forage & Concentrate \\
\hline Maize-whole plant dehydrated & 50.0 & - \\
Lucerne hay dehydrated & 50.0 & - \\
Lucerne meal pellets & - & 31.93 \\
Barley meal & - & 11.60 \\
Spanish ground maize & - & 11.80 \\
Soyabean meal, 44\% & - & 20.94 \\
Whole sunflower-seed meal & - & 22.40 \\
$\mathrm{CaCO}_{3}$ & - & 1.00 \\
Mineral-vitamin mix & - & 0.30 \\
Rovimix E-50 SD & - & 0.01 \\
Bioplex Zn & - & 0.02 \\
\hline
\end{tabular}

${ }^{1}$ mineral-vitamin mix was supplied by Agribrands Europe, Barcelona, Spain. The preparation contained, g/kg: Ca 105, Mn 20.0, Fe 17.5, Zn 15.0, I 250; mg/kg: Se 100; IU/kg: Co 50, vit. A 3600 vit. $\mathrm{D}_{3} 700$, vit. E 22000; ${ }^{2}$ Hoffmann-La Roche Ltd. Vitamins and Fine Chemicals Division (Basel, Switzerland), contained 50\% DL- $\alpha$-tocopheryl acetate; ${ }^{3}$ Alltech Ireland Ltd. (Dunboyne, Co. Meath, Ireland), contained $10 \% \mathrm{Zn}$

Table 2. Chemical composition and nutritive value of feeds used in the experimental diets

\begin{tabular}{|c|c|c|c|c|c|}
\hline \multirow{2}{*}{ Item } & \multirow{2}{*}{ Forage } & \multicolumn{2}{|c|}{ Concentrates } & \multicolumn{2}{|c|}{ TMR } \\
\hline & & control & enzyme $^{1}$ & control & enzyme \\
\hline DM content, $\%$ & 92.66 & 90.79 & 90.83 & 92.01 & 92.02 \\
\hline \multicolumn{6}{|c|}{ Composition, \% DM } \\
\hline organic matter & 91.5 & 90.4 & 90.2 & 91.1 & 91.0 \\
\hline crude protein & 11.2 & 23.8 & 24.6 & 15.6 & 15.9 \\
\hline NDF & 51.5 & 27.5 & 27.4 & 43.1 & 43.1 \\
\hline $\mathrm{ADF}$ & 30.3 & 16.8 & 17.6 & 25.6 & 25.9 \\
\hline $\mathrm{NE}_{\mathrm{I}}, \mathrm{MJ} / \mathrm{kg} \mathrm{DM}{ }^{2}$ & 5.68 & 6.31 & 6.31 & 5.89 & 5.89 \\
\hline $\mathrm{Ca}, \mathrm{g} / \mathrm{kg} \mathrm{DM}^{2}$ & 13.8 & 11.3 & 11.3 & 12.9 & 12.9 \\
\hline $\mathrm{P}, \mathrm{g} / \mathrm{kg} \mathrm{DM} \mathrm{DM}^{2}$ & 3.0 & 5.0 & 5.0 & 3.7 & 3.7 \\
\hline
\end{tabular}

${ }^{1}$ fibrolytic enzyme mixture (Promote, Promote Technologies Group, Agribrands, Minnetonka, USA) applied by spraying onto the cold concentrate pellets at $4.7 \mathrm{ml} / \mathrm{kg} ;{ }^{2}$ estimated from INRA Tables (Jarrige, 1989) 
The enzyme preparation was added to the concentrate, and was not given as a supplement or premix, according to Bowman et al. (2002). The liquid enzyme preparation was sprayed at the recommended commercial dose of $4.7 \mathrm{ml} / \mathrm{kg}$ of concentrate (P.Frumholtz, Agribrands International; personal communication), from a horizontal mixer onto the previously manufactured cold concentrate pellets (6 mm diameter). This enzyme dose represents $1.65 \mathrm{ml} / \mathrm{kg}$ of TMR which is in the range of the doses commonly used in similar experiments in ruminants (Beauchemin et al., 2003).

Diet was formulated using the INRAtion v.2.7 software and TMR was offered to each group once daily after milking $(10.00 \mathrm{~h})$ at $130 \%$ of the intake from the previous day. Fresh water supply was permanently available. Dry matter intake (DMI) of each goat group was calculated as the difference between total dry matter (DM) amount of TMR offered and refused daily for each pen. Samples of the concentrates, forage mixture and orts were separately collected daily, composited in weekly samples and finally composited by period and treatment for analysis.

Goats were milked once daily at $9.00 \mathrm{~h}$ in a 12 stall double parallel milking parlour with collecting jars (Westfalia Landtechnik, Granollers, Barcelona) using the normal milking parameters for the breed $(42 \mathrm{kPa}, 90$ pulsation rate, and $60 \%$ pulsation ratio). Milk production was recorded weekly for each goat throughout the experiment. One milk sample per goat was collected biweekly and preserved with potassium dichromate for analysis on the same day with 2 replicates per goat. Goat BW and BCS (on a scale of 1 to 5, according to Hervieu et al., 1991) were recorded weekly, beginning at wk 15 of lactation.

\section{Analytical procedures}

Feed samples were ground through a 1-mm stainless steel screen (Cyclotec 1093 Sample mill, Tecator, Hogänäs, Sweden) and analysed for DM and organic matter (OM) according to AOAC (1990). For crude protein (CP) a Kjeltec Auto 1030 Analyzer (Tecator, Hogänäs, Sweden) was used. The methods of Van Soest et al. (1991) were used for neutral detergent fibre (NDF) and acid detergent fibre (ADF) estimation determination on an ash-free basis using the Ankom ${ }^{200}$ Fibre Analyzer incubator (Ankom Technology, Macedon, New York, USA) adding amylase and sodium sulphite solutions. All analyses were done in duplicate. Milk samples were analysed by using near-infrared reflectance spectroscopy analysis (InfraAlyzer 450, Bran+Luebbe SL, Nordersted, Germany) according to Albanell et al. (1999).

Cellulase and xylanase activities of the commercial enzyme preparation used were 130 and 120,000 units/g, respectively (P. Frumholtz, Agribrands International, St. Louis, Missouri, USA; personal communication). Endoglucanase activity 
was checked by using acetic acid/di-sodium phosphate buffer $(\mathrm{pH} 6.5)$ and carboxymethylcellulose as substrate (sodium salt, medium viscosity; Sigma, St. Louis, Missouri, USA; C-5678). Concentrations of reducing sugars were determined by the Nelson-Somogyi copper reduction method (Somogyi, 1952) with glucose as the standard, and quantified spectrophotometrically at $520 \mathrm{~nm}$ (Spectrophotometer UV-120-01, Shimadzu, Kyoto, Japan).

\section{Calculations and statistical analyses}

Lactation effects, BW and BCS changes were analysed for each goat (individual data) using the PROC MIXED for repeated measurements of SAS (SAS 8.1; SAS Inst. Inc., Cary, NC, USA). The model included the fixed effects of treatment and period, the random effect of goat and the residual error.

\section{RESULTS AND DISCUSION}

Chemical composition of forage, concentrates and experimental TMR are shown in Table 2. Similar DM, OM, CP, NDF and ADF contents were achieved for both control and enzyme diets. Endoglucanase activity of the enzyme mixture was 850, 842 and $215 \mathrm{nmol}$ of glucose liberated per min, for $\mathrm{pH} 4.0,5.5$ and 6.5, respectively.

Ration DMI averaged $2.02 \pm 0.04 \mathrm{~kg} / \mathrm{d}$ (4.8\% of BW) from wk 10 to 26 of lactation, according to the value of DMI predicted by INRAtion v.2.7 $(2.1 \mathrm{~kg}$ $\mathrm{DM} / \mathrm{d}$ ), and was similar in both groups of goats. This result agrees with other studies in which no differences in DMI were reported in suckling goats and ewes (Titi and Lubbadeh, 2004; Flores et al., 2008), dairy sheep (Flores et al., 2002, 2008), beef steers (Feng et al., 1996), heifers (Hristov et al., 2000) or in dairy cows (Beauchemin et al., 1999; Yang et al., 1999; Kung et al., 2000; Bowman et al., 2002) when similar enzyme mixture with cellulase and xylanase activity were added to either TMR, forage or concentrate.

In contrast, other research has reported a positive effect of enzyme supplementation on DMI of dairy cows (Beauchemin et al., 2000) and feedlot cattle (Burroughs et al., 1960; Beauchemin et al., 1995), but this increase only produced a higher milk yield in the early lactation period under negative energy balance (Rode et al., 1999). An increase in DMI was also observed by PinosRodríguez et al. (2002) when fibrolytic enzyme was used in lambs. Differences reported in DMI effects between studies may also be due to the activity of the enzyme complex as well as to the experimental conditions used in each study.

Intro milk yield and $4 \%$ fat corrected milk (FCM) for goats supplemented with enzymes were not different from goats fed with the control diet in the 
lactation $(1.52 \pm 0.04 \mathrm{1} / \mathrm{d}$; Table 3$)$. Persistency coefficients throughout lactation were high $(96.5 \%$ per week) and also not affected by enzyme supplementation. These results agree with Beauchemin et al. $(1999,2000)$ who observed no effect of enzyme supplementation on actual or standardized milk yield in dairy cows. In contrast, others studies have reported that addition of enzymes to the TMR, forage or concentrate, increased milk yield (6 to 12\%) in suckling goats and ewes (Titi and Lubbadeh, 2004) and in dairy cows (Rode et al., 1999; Yang et al., 1999; Kung et al., 2000).

Table 3. Effects of enzyme supplementation on dry matter intake, milk production, and body weight and body condition score changes of lactating goats

\begin{tabular}{|c|c|c|c|c|}
\hline Item & Control & Enzyme & SEM & Effect $(\mathrm{P}<)$ \\
\hline \multicolumn{5}{|l|}{ Dry matter intake } \\
\hline $\mathrm{kg} / \mathrm{d}$ & 2.04 & 2.00 & 0.04 & - \\
\hline$\%$ of BW & 4.9 & 4.7 & 0.1 & - \\
\hline \multicolumn{5}{|c|}{ Milk production, l/d } \\
\hline actual & 1.51 & 1.53 & 0.04 & 0.29 \\
\hline $4 \% \mathrm{FCM}^{1}$ & 1.78 & 1.80 & 0.04 & 0.54 \\
\hline \multicolumn{5}{|c|}{ Milk composition, \% } \\
\hline total solids & 13.99 & 13.76 & 0.21 & 0.39 \\
\hline fat & 5.34 & 5.16 & 0.15 & 0.62 \\
\hline protein & 3.77 & 3.73 & 0.10 & 0.34 \\
\hline true protein & 3.54 & 3.53 & 0.11 & 0.39 \\
\hline casein & 2.87 & 2.81 & 0.12 & 0.09 \\
\hline \multicolumn{5}{|c|}{ Milk component yield, $g / d$} \\
\hline total solids & 210 & 210 & 13 & 0.64 \\
\hline fat & 81 & 79 & 11 & 0.62 \\
\hline protein & 67 & 67 & 10 & 0.58 \\
\hline true protein & 52 & 52 & 9 & 0.90 \\
\hline casein & 44 & 43 & 9 & 0.68 \\
\hline FCM/DMI & 0.87 & 0.90 & 0.02 & 0.21 \\
\hline \multicolumn{5}{|l|}{ Body change } \\
\hline $\mathrm{kg} \mathrm{BW}$ & -0.1 & 1.9 & 0.4 & 0.09 \\
\hline $\operatorname{BCS}(1 \text { to } 5)^{2}$ & 0.09 & 0.19 & 0.06 & 0.14 \\
\hline
\end{tabular}

${ }^{1}$ estimated according to equation of gaines: $\mathrm{kg}$ of $4 \% \mathrm{FCM}=[0.4+0.15 \times(\%$ fat $)] \times \mathrm{kg}$ milk 2 according to Hervieu et al. (1991)

Milk composition was not affected by experimental treatments during lactation being the average values of milk composition for both treatments: total solids $(13.89 \pm 0.21 \%)$, fat $(5.25 \pm 0.15 \%)$, total protein $(3.75 \pm 0.10 \%)$ and true protein $(3.54 \pm 0.11 \%)$. Milk casein content tended to decrease $(\mathrm{P}<0.10)$ by effect of enzyme supplementation (Table 3). Consequently, no differences were detected 
in the milk component yields either when enzyme supplemented and control diets were compared (Table 3). Similar results were obtained by Rode et al. (1999), Yang et al. (1999), Kung et al. (2000) and Sutton et al. (2003) in dairy cows. Nevertheless, Rode et al. (1999) reported a decrease in milk fat content, using a similar fibrolytic enzyme and application procedure than in our experiment and Titi and Lubbadeh (2004) reported an increase in milk fat and protein in suckling ewes. Moreover, Sutton et al. (2003) concluded that fibrolytic enzymes enhance particle outflow rate from the rumen and, in some instances, tend to shift fibre digestion from the rumen to the gut. The reasons are unclear and further research on the mode of action of fibrolytic enzymes is still necessary.

Enzyme supplementation tended $(\mathrm{P}<0.10)$ to improve BW change $(+2.0 \mathrm{~kg})$ throughout lactation.

\section{CONCLUSIONS}

Supplementing dairy goat diets with fibrolytic enzyme, under the conditions of this experiment, did not affect lactational performance, although milk casein content tended to decrease in the enzyme treatment. Further research is necessary to clarify if the concentration of the fibrolytic enzyme mixture, the application mode, the forage to concentrate ratio or the lactation stage were the variation factors responsible for the lack of effect of the fibrolytic enzyme supplementation.

\section{ACKNOWLEDGEMENTS}

The authors give thanks to Ramón Costa and the team of the "Servei de Granges i Camps Experimentals" of the UAB, for the care of animals, and to Nic Aldam for the English revision of the manuscript.

\section{REFERENCES}

Albanell E., Cáceres P., Caja G., Molina E., Gargouri A., 1999. Determination of fat, protein, and total solids in ovine milk by Near-Infrared Spectroscopy. J. AOAC Int. 82, 753-758

AOAC, 1990. Association of Official Analytical Chemists, Official Methods of Analysis. 15th Edition. Arlington, VA

Beauchemin K.A., Colombatto D., Yang W.Z., Morgavi D.P., 2003. Use of feed enzymes to improve feed utilization by ruminants. J. Anim. Sci. 81, Suppl. 2, E37-E47

Beauchemin K.A., Rode L.M., Maekawa M., Morgavi D.P., Kampen R., 2000. Evaluation of a nonstarch polysaccharidase feed enzyme in dairy cow diets. J. Dairy Sci. 83, 543-553 
Beauchemin K.A., Rode L.M., Sewalt V.J.H., 1995. Fibrolytic enzymes increase fiber digestibility and growth rate of steers fed dry forages. Can. J. Anim. Sci. 75, 641-644

Beauchemin K.A., Yang W.Z., Rode L.M., 1999. Effects of grain source and enzyme additive on site and extent of nutrient digestion in dairy cows. J. Dairy Sci. 82, 378-390

Bhat M.K., 2000. Cellulases and related enzymes in biotechnology. Biotechnol. Adv. 18, 355-383

Bowman G.R., Beauchemin K.A., Shelford J.A., 2002. The proportion of the diet to which fibrolytic enzymes are added affects nutrient digestion by lactating cows. J. Dairy Sci. 85, 3420-3429

Burroughs W., Woods W., Ewing S.A., Greig J., Theurer B., 1960. Enzyme additions to fattening cattle rations. J. Anim. Sci. 19, 458-464

Chesson A., 1993. Feed enzymes. Anim. Feed Sci. Tech. 45, 65-79

Feng P., Hunt C.W., Pritchard G.T., Julien W.E., 1996. Effect of enzyme preparations on in situ and in vitro degradation and in vivo digestive characteristics of mature cool-season grass forage in beef steers. J. Anim. Sci. 74, 1349-1357

Flores C., Caja G., Casals R., Albanell E., Such X., 2008. Performance of dairy ewes fed diets with a fibrolytic enzyme product included in the concentrate during the suckling period. Animal 2, 962-968

Flores C., Caja G., Casals R., Albanell E., Such X., Vera G., González E., Bach A., Torre C., 2002. Supplementation of a fibrolytic enzyme complex in the concentrate of dairy ewes during lactation. J. Anim. Sci. 80, Suppl. 1, 357 (Abstr. 1431)

Hervieu J., Morand-Fehr P., Schmidely Ph., Fedele V., Delfa R., 1991. Mesures anatomiques permettant d'expliquer les variations des notes sternales, lombaires et caudales utilisées pour estimer l'état corporel des chèvres laitières. Options Méditerranéennes, Sér. Séminaires 13, 43-56

Hristov A.N., McAllister T.A., Cheng K.J., 2000. Intraruminal supplementation with increasing levels of exogenous polysaccharide-degrading enzymes: Effects on nutrient digestion in cattle fed a barley grain diet. J. Anim. Sci. 78, 477-487

Jarrige R., 1989. Ruminant Nutrition. INRA Recommended Allowances and Feed Tables. Libbey Eurotex, Paris (France)

Kung Jr. L., Treacher R. J., Nauman G.A., Smagala A.M., Endres K.M., Cohen M.A., 2000. The effect of treating forages with fibrolytic enzymes on its nutritive value and lactation performance of dairy cows. J. Dairy Sci. 83, 115-122

Pinos-Rodríguez J.M., González S.S., Mendoza G.D., Bárcena R., Cobos M.A., Hernández A., Ortega M.E., 2002. Effects of exogenous fibrolytic enzyme on ruminal fermentation and digestibility of alfalfa and rye-grass hay fed to lambs. J. Anim. Sci. 80, 3016-3020

Rode L.M., Yang W.Z., Beauchemin K.A., 1999. Fibrolytic enzyme supplements for dairy cows in early lactation. J. Dairy Sci. 82, 2121-2126

Somogyi M., 1952. Notes on sugar determination. J. Biol. Chem. 195, 19-23

Sutton J.D., Phipps R.H., Beever D.E., Humphries D.J., Hartnell G.F., Vicini J.L., Hard D.L., 2003. Effect of method of application of a fibrolytic enzyme product on digestive processes and milk production in Holstein-Friesian cows. J. Dairy Sci. 86, 546-556

Titi H., Lubbadeh W.F., 2004. Effect of feeding cellulose enzyme on productive responses of pregnant and lactating ewes and goats. Small Ruminant Res. 52, 137-143

Van Soest P.J., Robertson J.B., Lewis B.A., 1991. Methods for dietary fiber, neutral detergent fiber and nonstarch polysaccharides in relation to animal nutrition. J. Dairy Sci. 74, 3583-3597

Yang W.Z., Beauchemin K.A., Rode L.M., 1999. Effects of an enzyme feed additive on extent of digestion and milk production of lactating dairy cows. J. Dairy Sci. 82, 391-403 